
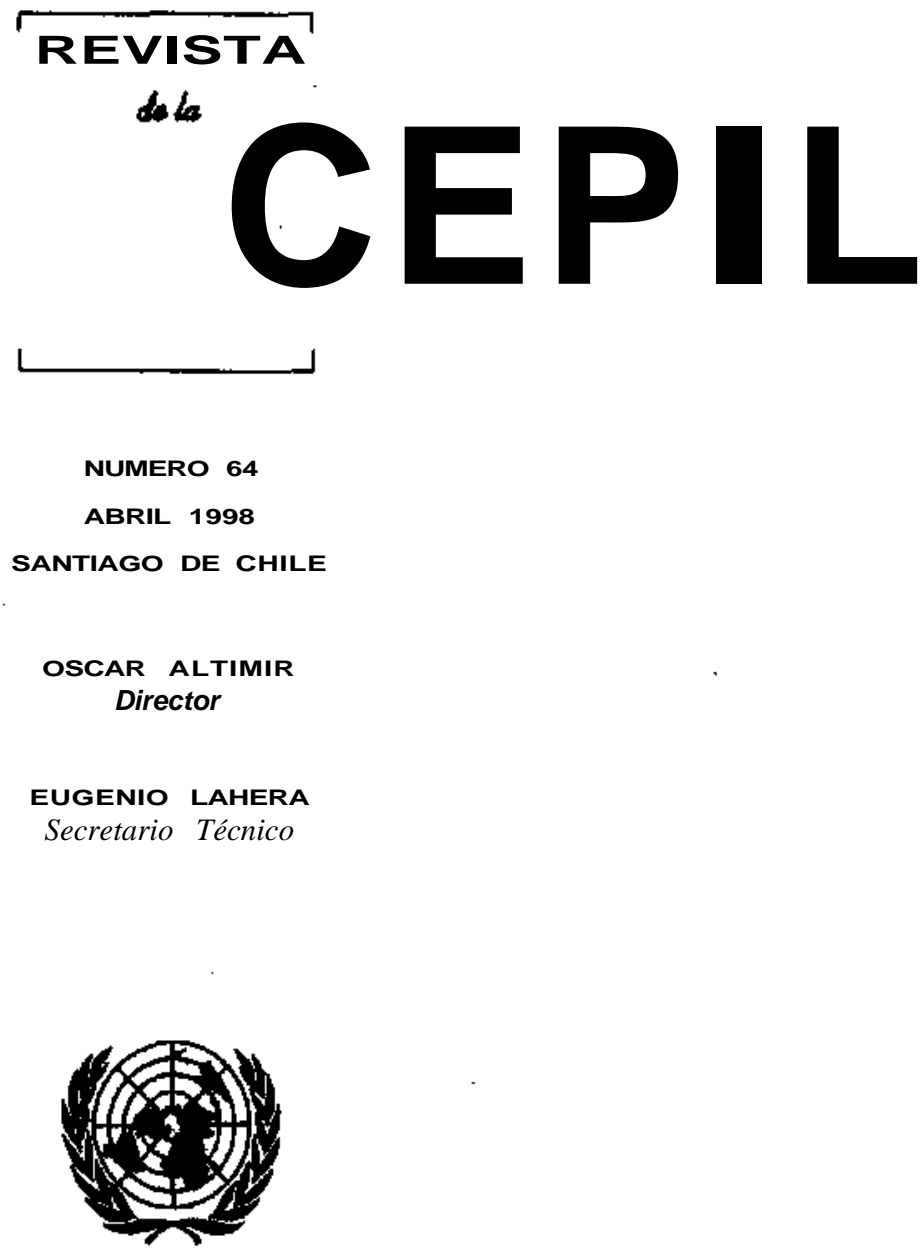

NACIONES UNIDAS 
Instituciones y crecimiento ¿Puede el capital humano ser un vínculo?

Nauro Campos y Jeffrey B. Nugent

Flujos de capital externo en América Latina y el Caribe en los años noventa: experiencias y políticas

Gunther Held y Raquel Szalachman

El Banco Central y la política macroeconómica de Chile en ios años noventa

Roberto Zahler

Política fiscal, ciclo y crecimiento

Ricardo Mariner

La convergencia hacia mejores prácticas productivas y de políticas: el acuerdo de la OMC sobre medidas de inversión vinculadas al comercio

Francisco Sercovich

Efectos para América Latina de la expansión de la Unión Europea

Peter Nunnenkamp

La dimensión Norte-Sur de las industrias de limpieza ambiental

y la difusión de tecnologías limpias

Jonathan R. Barton

La evolución del papel del Estado en la regulación del transporte terrestre

Ian Thomson

Manejo integrado del recurso agua, con la perspectiva de los

Principios de Dublin

Miguel Solanes

Publicaciones recientes de la CEPAL 


\section{Efectos para América Latina de la expansión de la Unión Europea}

Peter Nunnenkamp

Instituto de Economía Mundial de Kiel, Alemania
La inminente extensión de la Unión Europea hacia el este ha reavivado la inquietud en América Latina por la posibilidad de un mayor aislacionismo en Europa. Sin embargo, es difícil que perjudique a América Latina el auge de las relaciones en materia de comercio e inversión extranjera directa entre los miembros actuales de la Unión Europea y los países de Europa central y oriental. Por su composición, parece que las exportaciones de América Latina a la Unión Europea complementan las de los países de Europa central y oriental. Además, la masiva afluencia reciente de inversión extranjera directa a varios países receptores, entre ellos varios latinoamericanos, estaría indicando que las nuevas posibilidades de inversión en los países de Europa central y oriental se traducirán en un aumento, y no en una desviación, de esa inversión. Es difícil que este cuadro se modifique gran cosa cuando estos países se conviertan en miembros de la Unión Europea. En este artículo se concluye que las relaciones económicas futuras entre América Latina y la Unión Europea dependen sobre todo de la reforma sostenida de la política económica latinoamericana y del papel de la Unión Europea en tas negociaciones comerciales multilaterales, más bien que de la ampliación de la Unión con el ingreso de nuevos países. 


\section{Introducción}

La ampliación de la Unión Europea con el ingreso de los países de Europa central y oriental puede plantear un dilema para América Latina. Por una parte, a la región le interesa el éxito de la integración de los países de Europa central y oriental en la Unión Europea, ${ }^{1}$ ya que los exportadores latinoamericanos podrán encontrar nuevos y boyantes mercados en esos países si la transición económica y la integración se realizan sin tropiezos. En cambio, si la extensión de la Unión Europea hacia el este no prosperara, casi con seguridad se producirá la desestabilización económica y política de los países de Europea central y oriental. Las repercusiones de este fracaso podrían difundirse fácilmente más allá de Europa occidental. Los países no miembros de la Unión serían los más afectados por la tensión económica y política entre la Unión Europea y los países de Europa central y oriental, ya que se le restaría confiabilidad a la Unión Europea en sus relaciones de comercio e inversión con todos los países no miembros, incluso los de América Latina.

Por otra parte, la inminente extensión de la Unión Europea ha reavivado la preocupación de que Europa se vuelva más aislacionista. En muchos países latinoamericanos está muy arraigada la convicción de que se les discrimina frente a los proveedores internos de la Unión Europea y sus clientes privilegiados. Por cierto que cabe esperar efectos discriminatorios adversos si los países candidatos a miembros de la Unión Europea compiten directamente con América Latina en las exportaciones a la Unión y en los esfuerzos por atraer la inversión extranjera directa.

En principio, se justifica la preocupación por una posible desviación del comercio y de la inversión resultante de la extensión de la Unión Europea hacia el este. Varias razones, sin embargo, estarían indicando que es poco probable que América Latina se vea afectada por efectos importantes de desviación. Esta proposición se corrobora analizando, primero, la estructura reciente del comercio (sección II) y, luego, la cuestión de la competencia por la inversión extranjera directa (sección III). La evaluación toma en cuenta que las tendencias recientes pueden variar una vez que los países de Europa central y oriental pasen a ser miembros de la Unión (sección IV). Se concluye que lo más probable es que las relaciones económicas entre América Latina y la Unión Europea prosperen si la integración se realiza sin tropiezos y si América Latina aplica reformas sostenidas a su política económica.

\section{II}

\section{La estructura de las importaciones de la Unión Europea: por qué las preferencias comerciales no constituyen una explicación suficiente}

1. El auge del comercio este-oeste ¿un caso de
desviación del comercio?

Los países de Europa central y oriental se han beneficiado de un viraje sin precedentes de la posición de la Unión Europea en materia de política comercial. En la

\footnotetext{
${ }^{1}$ Para una argumentación similar, véase Langhammer y Nunnenkamp (1993).
}

era socialista, estos países tenían graves limitaciones para acceder al mercado de la Unión, con aranceles elevados, restricciones cuantitativas y gran variedad de medidas condicionales proteccionistas. En esa época, figuraban en la base de la pirámide de preferencias comerciales que otorgaba la Unión Europea a varios grupos de países (Hiemenz, Gundlach, Langhammer y Nunnenkamp, 1994 pp. 18 y siguientes). La liberalización del comercio entre este y oeste comenzó en 1988 (cuando la Unión Europea suscribió un acuerdo 
de comercio y cooperación con Hungría), pero el cambio fundamental se produjo en 1991: los llamados acuerdos de asociación ("Europa") elevaron a la ex Checoslovaquia, Hungría y Polonia al vértice de la pirámide de preferencias comerciales.

Es evidente que este viraje explica el auge de las importaciones de la Unión Europea provenientes de los países de Europa central y oriental. Las importaciones de un grupo de siete de estos países ${ }^{2}$ se quintuplicaron entre 1986 y 1995 (OCDE, Foreign Trade by Commodities. Series $C$, varios números). Las importaciones de la Unión provenientes de América Latina, partiendo de un nivel más elevado, apenas si se duplicaron durante el mismo período. En 1995, las importaciones provenientes de los siete países europeos superaron a las procedentes de todas las economías latinoamericanas. Es bastante razonable suponer que se mantendrá la tendencia a un crecimiento mucho más rápido de las importaciones de la Unión Europea provenientes de los países de Europa central y oriental, considerando que algunos de éstos se integrarán pronto a la Unión.

Sin embargo, cabe preguntarse si el auge de las importaciones de la Unión Europea provenientes de los países de Europa central y oriental se hizo (o se hará) a expensas de otros países con que mantienen relaciones comerciales y de América Latina en particular. Asimismo, no se sabe en qué medida el auge de las importaciones obedeció al acceso preferencial de los países de Europa central y oriental a los mercados de la Unión Europea. Los patrones comerciales históricos del período entre guerras así como la simulación de patrones comerciales "normales" ${ }^{3}$ indican que estos países orientarían en todo caso la proporción mayoritaria de sus exportaciones a Europa occidental. Dos razones explican por qué sus exportaciones a la Unión Europea no alcanzaron su patrón "normal" hasta comienzos del decenio de 1990: aparte las restricciones comerciales que imponía la Unión Europea, estos países, en condiciones de planificación centralizada, experimentaron un deterioro de su capacidad de oferta. En otras palabras, lo más probable es que su transformación económica habría resultado en un aumento de las exportaciones a la Unión Europea, aun sin el acceso preferencial a ese mercado.

\footnotetext{
${ }^{2}$ Albania, Bulgaria, Hungría, Polonia, Rumania, República Checa y República Eslovaca,

${ }^{3}$ Calculados aplicando modelos gravimétricos que consideran el tamaño económico y la distancia como los determinantes principales de la dirección del comercio; véase, por ejemplo, Piazolo (1997).
}

Esto implica que el aumento de las importaciones de la Unión Europea desde esos países es un efecto de la creación de comercio, y no de la desviación provocada por las preferencias. ${ }^{4}$ Es casi imposible evaluar empíricamente la importancia relativa de la creación o de la desviación de comercio. Sin embargo, una evaluación más a fondo sugiere que las políticas comerciales de la Unión Europea hacia los países de Europa central y oriental son de importancia secundaria para explicar la posición competitiva de América Latina en los mercados de bienes de la Unión.

\section{Los países de Europa central y oriental y Amé- rica Latina ¿proveedores que compiten en los mercados de la Unión Europea?}

La desviación del comercio en perjuicio de América Latina sería muy probable si fueran elevadas las elasticidades de sustitución entre los proveedores (preferidos) de los países europeos y los proveedores (no preferidos) de América Latina en los mercados de la Unión Europea. Como es difícil medir directamente las elasticidades de sustitución, los índices de superposición del comercio suelen usarse como indicadores indirectos (Langhammer, 1944), Al comparar la estructura de los bienes importados por la Unión Europea desde los países de Europa central y oriental y desde América Latina en su conjunto se advierte un grado sorprendentemente bajo de superposición. Tal vez lo más notorio sea que las manufacturas representaban el $70 \%$ del total de importaciones desde los países de Europa central y oriental, mientras que esa participación era sólo de $20 \%$ para América Latina (véase el cuadro 1).

Podría suponerse que el gran aumento de la proporción de manufacturas en las importaciones de la Unión Europea desde los países de Europa central y oriental a contar de 1989 ha impedido que América Latina reduzca el fuerte sesgo a favor de los bienes no manufacturados (como alimentos, materias primas y otros productos básicos) en sus exportaciones a la Unión Europea. En realidad, es notorio que, a diferencia de las importaciones de la Unión Europea, las de los Estados Unidos provenientes de América Latina muestran una proporción mucho más alta de manufac-

\footnotetext{
${ }^{4}$ A partir de una comparación entre la ventaja relativa manifiesta de los países de Europa central y oriental en la Unión Europea frente a todos los demás países que entran en ese comercio, Piazolo (1997) concluyó que era improbable que la integración regional que beneficia al comercio intraeuropeo llevara a distorsiones marcadas.
} 
CUADRO 1

Unión Europea: Composición de las importaciones provenientes de los países de Europa central y oriental y de América Latina, 1989 y 1994

(En porcentaje)

\begin{tabular}{|c|c|c|c|c|c|}
\hline & & $\begin{array}{c}\text { Bienes } \\
\text { manufacturados } \\
\text { (importaciones } \\
\text { totales }=100 \text { ) }\end{array}$ & $\begin{array}{l}\text { Productos } \\
\text { químicos }\end{array}$ & $\begin{array}{l}\text { Industrias seleccionadas } \\
\text { (importaciones de } \\
\text { manufacturas }=100 \text { ) } \\
\text { Maquinaria y equipo de } \\
\text { transporte }\end{array}$ & $\begin{array}{l}\text { Textiles, } \\
\text { vestuario } \\
\text { y cuero }\end{array}$ \\
\hline $\begin{array}{l}\text { Países de Europa } \\
\text { central y oriental }\end{array}$ & $\begin{array}{l}1989 \\
1994\end{array}$ & $\begin{array}{l}49.4 \\
70.3\end{array}$ & $\begin{array}{l}16.4 \\
9.3\end{array}$ & $\begin{array}{l}22.4 \\
29.7\end{array}$ & $\begin{array}{l}30.4 \\
30.0\end{array}$ \\
\hline América Latina & $\begin{array}{l}1989 \\
1994\end{array}$ & $\begin{array}{r}19.4 \\
20.4\end{array}$ & $\begin{array}{l}17.6 \\
16.5\end{array}$ & $\begin{array}{l}37.5 \\
34.7\end{array}$ & $\begin{array}{l}24.3 \\
23.3\end{array}$ \\
\hline Argentina & $\begin{array}{l}1989 \\
1994\end{array}$ & $\begin{array}{l}14.7 \\
14.1\end{array}$ & $\begin{array}{l}34.9 \\
21.4\end{array}$ & $\begin{array}{l}13.6 \\
22.1\end{array}$ & $\begin{array}{l}39.6 \\
39.9\end{array}$ \\
\hline Brasil & $\begin{array}{l}1989 \\
1994\end{array}$ & $\begin{array}{l}29.3 \\
27.4\end{array}$ & $\begin{array}{l}12.9 \\
12.2\end{array}$ & $\begin{array}{l}41.3 \\
33.0\end{array}$ & $\begin{array}{l}24.3 \\
24.4\end{array}$ \\
\hline Chile & $\begin{array}{l}1989 \\
1994\end{array}$ & $\begin{array}{l}3.5 \\
7.3\end{array}$ & $\begin{array}{l}71.6 \\
61.6\end{array}$ & $\begin{array}{l}4.5 \\
7.6\end{array}$ & $\begin{array}{l}5.0 \\
7.2\end{array}$ \\
\hline México & $\begin{array}{l}1989 \\
1994\end{array}$ & $\begin{array}{l}28.5 \\
47.0\end{array}$ & $\begin{array}{l}19.3 \\
16.4\end{array}$ & $\begin{array}{l}58.2 \\
57.4\end{array}$ & $\begin{array}{r}10.2 \\
7.2\end{array}$ \\
\hline
\end{tabular}

Fuente: OCDE, Foreign Trade by Commodities. Series C. (varios números).

a cuci, secciones 5 a 8 , menos capítulos 67 y 68 .

b CUCI, sección 5.

c CUCl, sección 7 ,

${ }^{d}$ CUCI, capítulos 61, 65, 84 y 85 .

e Sin la Comunidad de Estados Independientes.

turas a comienzos del decenio de $1990 .^{5}$ Sin embargo, hay varias observaciones que contradicen esa apreciación. Para América Latina en su conjunto, los hechos escuetos eran los siguientes:

- $\quad$ La proporción de manufacturas en las exportaciones latinoamericanas era un $50 \%$ menor en el mercado de la Unión Europea que en el mercado estadounidense, incluso antes de que la Unión diera a los países de Europa central y oriental una condición de privilegio (Naciones Unidas, 1996).

- Al analizar las cifras por tipo de industria manufacturera, no se advierte que las variaciones estructurales de las importaciones de la Unión Europea desde los países de Europa central y oriental estuvieran relacionadas con variaciones similares en las importaciones desde América Latina. ${ }^{6}$

\footnotetext{
${ }^{5}$ Esa proporción casi se duplica, de $31 \%$ en 1990 a $60 \%$ en 1994 (Naciones Unidas, 1996).

${ }^{6}$ El cuadro 1 incluye tres prototipos de industrias manufactureras: la industria química, que requiere relativamente gran densidad de capital físico; la maquinaria y equipo de transporte donde las tecnologías de producción tienden a un uso relativamente intensivo de personal especializado; y los textiles, el vestuario y el cuero cuya producción requiere relativamente gran cantidad de mano de obra (no calificada).
}

Las participaciones de los productos químicos, la maquinaria y el equipo de transporte, y los textiles, el vestuario y el cuero en las importaciones de manufacturas de la Unión Europea desde América Latina declinaron todas ligeramente, cualquiera fuera la variación que registraban esas partidas en las importaciones de manufacturas desde los países de Europa central y oriental (véase el cuadro 1).

- Por último, el grueso de las manufacturas de los proveedores latinoamericanos tiene acceso a los mercados de la Unión Europea casi sin restricciones. En otras palabras, los márgenes de preferencia que favorecen a los países de Europa central y oriental desempeñan un papel insignificante en gran parte de las manufacturas. Esto obedece también a que un $60 \%$ de las exportaciones latinoamericanas de bienes elaborados y semielaborados entran de hecho a los mercados de la Unión Europea libres de derechos o con desgravámenes conforme al Sistema Generalizado de Preferencias (Unión Europea, EUROSTAT, 1995). 
Como es evidente, los promedios para América Latina en su conjunto ocultan grandes diferencias entre países. Para cuatro economías latinoamericanas importantes, la proporción de las manufacturas en las importaciones de la Unión Europea iba de $7 \%$ para Chile a $47 \%$ para México (véase el cuadro 1). Con todo, las estadísticas por país tienden a apoyar la tesis de que la desviación del comercio desempeñó un papel secundario. Por ejemplo, México y, en menor medida, Chile, elevaron la proporción de sus manufacturas en las exportaciones totales a la Unión Europea, pese a que al mismo tiempo aumentaban las importaciones de manufacturas de la Unión Europea desde los países de Europa central y oriental. Además, no es lógico achacar a la desviación del comercio la ligera disminución de la proporción de las manufacturas en las exportaciones de Argentina y Brasil a la Unión Europea. Las variaciones en la participación de determinadas industrias en las importaciones de manufacturas de la Unión Europea desde Argentina se correlacionaban exactamente con las variaciones en (a participación de estas industrias en las importaciones de la Unión Europea desde los países de Europa central y oriental. En el caso de Brasil, la participación de la maquinaria y el equipo de transporte declinó considerablemente. Aunque aumentaron en gran medida las importaciones de este rubro de la Unión Europea desde los países de Europa central y oriental, es improbable que Brasil haya sufrido por la de desviación del comercio. Más bien, su menor participación parece fundarse en factores peculiares del país que redujeron capacidad de competencia internacional. De otra manera, sería difícil explicarse por qué aumentó la participación de la misma industria para Argentina y Chile, y siguió siendo extraordinariamente alta para México.

Habría que examinar más de cerca las superposiciones del comercio en las llamadas áreas sensibles. Tradicionalmente, las importaciones de acero, textiles y productos agrícolas de la Unión Europea estaban sujetas a cupos. Fue sobre todo en esos rubros que la Unión Europea otorgó un trato preferencial a los países de Europa central y oriental, lo que pudo haber causado desviación del comercio. Sin embargo, los análisis empíricos revelan escasa superposición entre la oferta de los países de Europa central y oriental y la de América Latina en los mercados de la Unión Europea sujetos a cupos (Langhammer, 1994).

Respecto al acero, las superposiciones del comercio a fines de los años ochenta y comienzos de los noventa se debían sobre todo a la competencia entre Brasil y la ex Unión Soviética en aceros especiales. Sin embargo, el descenso de la participación del Brasil en el mercado no puede explicarse por los márgenes de preferencia, sino que por la rebaja de precios de los Estados sucesores de la Unión Soviética. La desviación del comercio provocada por este factor disminuyó a contar de 1992-1993: la Unión Europea puso en vigor un "acuerdo de ordenación del mercado", impuso restricciones cuantitativas a las importaciones de acero de las repúblicas de la Comunidad de Estados Independientes, y a las de las repúblicas Checa y Eslovaca las sometió a contingentes arancelarios (OMC, 1995, p. 59). América Latina y los países de Europa central y oriental se vieron sometidos a una estrategia de "comercio dirigido" por parte de la Unión Europea, destinada a proteger a las siderurgias de la Unión y a los proveedores tradicionales contra un supuesto dumping. De hecho, la participación de los productos siderúrgicos en las exportaciones totales a la Unión Europea disminuyó tanto para América Latina como para los países de Europa central y oriental. ${ }^{7}$

América Latina tampoco parece haber sufrido una desviación considerable del comercio con respecto a los textiles y el vestuario. La participación de América Latina en las importaciones de la Unión Europea de estos productos (capítulos 65 y 84 de la cuci) de todos los países no pertenecientes a la OCDE disminuyó de $2.9 \%$ en 1989 a $1.7 \%$ en 1994 , mientras que la participación de los países de Europa central y oriental se duplicaban con creces al llegar a 16.2\% (OCDE, Foreign Trade by Commodities. Series $C$, varios números). ${ }^{8}$ Sin embargo, la disminución de la cuota de mercado de América Latina fue incluso más pronunciada en los años ochenta, ${ }^{9}$ es decir, antes de que esos países pasaran a ser los más favorecidos en el comercio de la Unión Europea. Es más, entre 1989 y 1994 América

\footnotetext{
${ }^{7}$ En 1989 los productos siderúrgicos representaban 7\% de las importaciones totales de la Unión Europea provenientes de los países de Europa central y oriental y 3,2\% de las importaciones totales de la Unión Europea desde América Latina; las cifras bajaron a 5.5\% y 1.4\%, respectivamente, en 1994 (OCDE, Foreign Trade by Commodities. Series $C$, varios números).

${ }^{8} \mathrm{El}$ alza vertiginosa de las importaciones de textiles y vestuario de la Unión Europea desde los países de Europa central y oriental parece obedecer en gran medida a actividades de ensamblaje de producciones subcontratadas por empresas de la Unión Europea en esos países (Nunnenkamp, Gundlach y Agarwal, 1994, p. 76). En cambio, no parece desempeñar un papel importante en las exportaciones de América Latina a la Unión Europea. Esto implica que los patrones de comercio de textiles y vestuario están sesgados a favor de los países europeos, si se considera que las reexportaciones elaboradas a la Unión Europea están infladas por la importación de insumos no elaborados provenientes de esa unión.

${ }^{9}$ En 1980, América Latina representó el $5.8 \%$ de las importaciones de textiles y vestuario de la Unión provenientes de todas las fuentes no pertenecientes a la OCDE (OCDE, Foreign Trade by Commodities. Seríes $\mathrm{C}$, varios números).
} 
Latina experimentó una declinación similar en su participación en las importaciones totales de manufacturas de la Unión Europea (de $7.1 \%$ a $4.5 \%$; véase el cuadro 2). Los datos por países presentados en el cuadro 1 revelan que sólo en el caso de México los textiles, el vestuario y el cuero tuvieron una participación declinante en las exportaciones de manufacturas a la Unión Europea. Todo esto implica que el trato preferencial otorgado a las importaciones de textiles y vestuario provenientes de los países de Europa central y oriental no es explicación suficiente del mal desempeño de América Latina. Por su parte, las preferencias otorgadas a los países de Europa central y oriental fueron de menor envergadura de lo que sugiere la eliminación de las restricciones cuantitativas. A semejan- za de los productos siderúrgicos, la desviación del comercio inducida por las preferencias favorables a las importaciones de textiles y vestuario provenientes de los países de Europa central y oriental se vio frenada por una vigilancia comercial persistente por parte de la Unión Europea. Las preferencias restantes se seguirán reduciendo una vez que el comercio internacional de textiles y vestuario se someta a la disciplina de la OMC, según lo convenido en la Ronda Uruguay.

El valor de las preferencias comerciales otorgadas a los países de Europa central y oriental fue demasiado elevado para los productos amparados por la política agrícola común. No obstante, la magnitud de la desviación del comercio que afecta a América Latina no parece ser tanta como suele creerse generalmente

CUADRO 2

Unión Europea: Estructura regional de las importaciones provenientes de países no pertenecientes a la OCDE, ${ }^{\mathrm{A}} 1989-1994$

(En porcentaje)

\begin{tabular}{|c|c|c|c|c|c|c|}
\hline & & Total & $\begin{array}{c}\text { Bienes } \\
\text { manufacturados }\end{array}$ & $\begin{array}{l}\text { Productos } \\
\text { químicos }\end{array}$ & $\begin{array}{l}\text { Maquinaria y equipo } \\
\text { de transporte" }\end{array}$ & $\begin{array}{c}\text { Textiles, vestuario } \\
\text { y cuero }\end{array}$ \\
\hline \multirow[t]{2}{*}{ África ${ }^{\mathrm{f}}$} & 1989 & 9.1 & 3.7 & 5.3 & 0.9 & 2.7 \\
\hline & 1994 & 6.6 & 2.3 & 1.4 & 0.6 & 2,2 \\
\hline \multirow{2}{*}{$\mathrm{Asia}^{\mathrm{G}}$} & 1989 & 30.4 & 60.6 & 20.3 & 68.9 & 63.1 \\
\hline & 1994 & 38.7 & 62.0 & 28.0 & 72.0 & 60.2 \\
\hline \multicolumn{7}{|l|}{ Europa } \\
\hline central & 1989 & 6.6 & 8.0 & 14.3 & 6.0 & 7.4 \\
\hline y oriental ${ }^{11}$ & 1994 & 13.1 & 16.7 & 20.9 & 14.3 & 16.2 \\
\hline \multirow{2}{*}{$\begin{array}{l}\text { Maghreb y } \\
\text { Mashrek }^{\mathrm{i}}\end{array}$} & 1989 & 7.5 & 4.3 & 8.0 & 1.7 & 8.4 \\
\hline & 1994 & 6.9 & 4.4 & 6.4 & 1.7 & 10.2 \\
\hline \multirow{2}{*}{$\begin{array}{l}\text { América } \\
\text { Latina }\end{array}$} & 1989 & 14.9 & 7.1 & 13.6 & 9.0 & 5.3 \\
\hline & 1994 & 12.2 & 4.5 & 10.1 & 4.6 & 3,4 \\
\hline \multirow[t]{2}{*}{ Argentina } & 1989 & 1.52 & 0.55 & 2.09 & 0.25 & 0.66 \\
\hline & 1994 & 1.57 & 0.40 & 1.16 & 0.26 & 0.52 \\
\hline \multirow[t]{2}{*}{ Brasil } & 1989 & 5.66 & 4.05 & 5.70 & 5.63 & 3.01 \\
\hline & 1994 & 4.42 & 2.21 & 3.60 & 2.09 & 1.74 \\
\hline \multirow[t]{2}{*}{ Chile } & 1989 & 1.39 & 0.12 & 0.92 & 0.02 & 0.02 \\
\hline & 1994 & 0.99 & 0.13 & 1.08 & 0.03 & 0.03 \\
\hline \multirow[t]{2}{*}{ México } & 19S9 & 1.49 & i. 04 & 2,19 & 2.03 & 0.32 \\
\hline & 1994 & 1.06 & 0.91 & 2.00 & 1.50 & 0.21 \\
\hline
\end{tabular}

Fuente: OCDE, Foreign Trade by Commodities. Series C. (varios números).

a Incluido México.

b cuCI, 5-8 excepto 67 y 68 .

c cuci, 5.

${ }^{d}$ cuci, 7.

c cuci, 61,65, 84 y 85 .

Excluidos Argelia, Egipto, Libia, Marruecos, Túnez y Sudáfrica.

$£$ Excluido el Oriente medio.

$\wedge$ Excluida la Comunidad de Estados Independientes.

Excluido Líbano. 
(Langhammer, 1994) $;^{10} 1^{\circ}$ Los productos amparados por esa política y exportados por los países de Europa central y oriental representaban en 1992 menos de un tercio de ese tipo de productos exportados por América Latina $;{ }^{11} 2^{\circ}$ las superposiciones en materia de oferta de alimentos en los mercados de la Unión Europea entre los países de Europa central y oriental, por una parte, y América Latina, por otra, fueron incluso menores que para el acero y los textiles; y $3^{\circ}$ a semejanza de los textiles, los márgenes de preferencia a favor de los países europeos se reducirán una vez que los acuerdos de la Ronda-Uruguay sobre agricultura se ejecuten plenamente.

La experiencia de Argentina es muy elocuente para evaluar la desviación del comercio en la agricultura. Un 60\% de las exportaciones de Argentina a la Unión Europea son alimentos (cuci, sección O). ${ }^{12}$ Este porcentaje permaneció casi constante desde 1989 hasta 1994 (OCDE, Foreign Trade by Commodities. Series $C$, varios números). Cabe suponer que, debido a su alta dependencia de las exportaciones alimentarias, Argentina haya sido la primera en sufrir la desviación del comercio en la agricultura. Sin embargo, de las cuatro economías latinoamericanas en estudio, Argentina fue la que mejor se desenvolvió en los mercados de la Unión Europea, ya que fue la única que registró un (modesto) incremento de su cuota global en ese mercado (véase el cuadro 2). Entre 1989 y 1994, las exportaciones de Argentina a la Unión Europea aumentaron por un factor de 1.4, comparadas con un factor de 1.1 para América Latina en su conjunto. Y lo que es aún más notable, las exportaciones no manufactureras fueron las que contribuyeron en mayor medida a

\footnotetext{
${ }^{10}$ Koester (1996) analiza en detalle el impacto de la política agrícola de la Unión Europea respecto a los países de Europa central y oriental sobre jos países en desarrollo, Observa que los países menos desarrollados se verán seguramente afectados en parte por el aumento de las exportaciones preferenciales de los países de Europa central y oriental a la Unión Europea. Sin embargo, lo más probable es que este efecto sea mínimo, ya que los países menos desarrollados venden un conjunto de productos que sólo compiten indirectamente mediante la incidencia recíproca de los precios de bienes sustitutivos con los productos que proveen los países de Europa central y oriental \{Koester, 1996, p. 174).

${ }^{11} \mathrm{El}$ análisis de las importaciones de alimentos, bebidas y tabaco de la Unión Europea sugiere que América Latina ha seguido siendo un proveedor más importante que los países de Europa central y oriental. En 1994, ellos (excluida la ex Unión Soviética) exportaron alrededor de 3000 millones de dólares de estos productos a la Unión Europea, frente a los 13500 millones que exportó América Latina (Naciones Unidas, 1996).

${ }^{12}$ Comparadas con un 35\% para Brasil, $28 \%$ para Chile y $69 \%$ para México en 1994 (OCDE, Foreign Trade by Commodities. Series C, varios números).
}

este resultado. ${ }^{13}$ En 1994, las importaciones de la Unión Europea de alimentos provenientes de Argentina superaron en 40\% a las de 1989 (OCDE, Foreign Trade by Commodities. Series $C$, varios números).

\section{La posición de América Latina en los merca- dos de la Unión Europea: ¿quién tiene la cul- pa?}

Las variaciones de la estructura regional de las importaciones de la Unión Europea provenientes de todos los países no pertenecientes a la OCDE apoyan el planteamiento de que el mal desempeño relativo de América Latina en los mercados de la Unión Europea no puede atribuirse a la existencia de vínculos institucionales más estrechos con los países de Europa central y oriental o al otorgamiento de preferencias comerciales a estos últimos. Si las políticas comerciales discriminatorias de la Unión hubieran sido el factor determinante en configurar las variaciones de las cuotas de mercado, los proveedores asiáticos habrían sido los primeros en sufrir la desviación del comercio, ya que ellos, sobre todo los de industrialización reciente, fueron el objetivo primordial de los instrumentos de política comercial discriminatoria aplicados por la Unión Europea (como los acuerdos de restricción de las exportaciones y las medidas antidumping) (Hiemenz, Gundlach, Langhammer y Nunnenkamp, 1994, pp. 65 a 67). ${ }^{14}$

En cambio, entre 1989 y 1994 Asia consolidó aún más su posición dominante entre los proveedores de bienes manufacturados no pertenecientes a la OCDE en los mercados de la Unión (véase el gráfico 1; para detalles véase el cuadro 2). ${ }^{15}$ Asia conquistó cuotas de mercado en industrias de uso internos de capital y mano de obra calificada como las de productos químicos y maquinaria y equipo de transporte, en tanto que su cuota disminuyó ligeramente en las importaciones de la Unión Europea de textiles, vestuario y cuero, que requieren gran cantidad de mano de obra no calificada.

En marcado contraste con Asia, la posición competitiva de América Latina en los mercados de la Unión Europea se deterioró en el período 1989-1994, tanto para el comercio total como para el comercio de manufacturas. La cuota de mercado de América Latina

\footnotetext{
${ }^{13}$ Nótese que la participación de Argentina en las importaciones de manufacturas de la Unión Europea disminuyó entre 1989 y 1994 (véase el cuadro 2).

${ }^{14}$ Las recientes investigaciones sobre antidumping abarcaron a varios proveedores asiáticos, incluidos India, Indonesia, Malasia $y$ Tailandia (OMC, 1995).

${ }^{15}$ Para un análisis detallado véase Agarwal, Langhammer, Lücke y Nunnenkamp (1995).
} 
Unión Europea: Estructura regional de las importaciones de manufacturas provenientes de países no pertenecientes a la OCDE (En porcentaje)
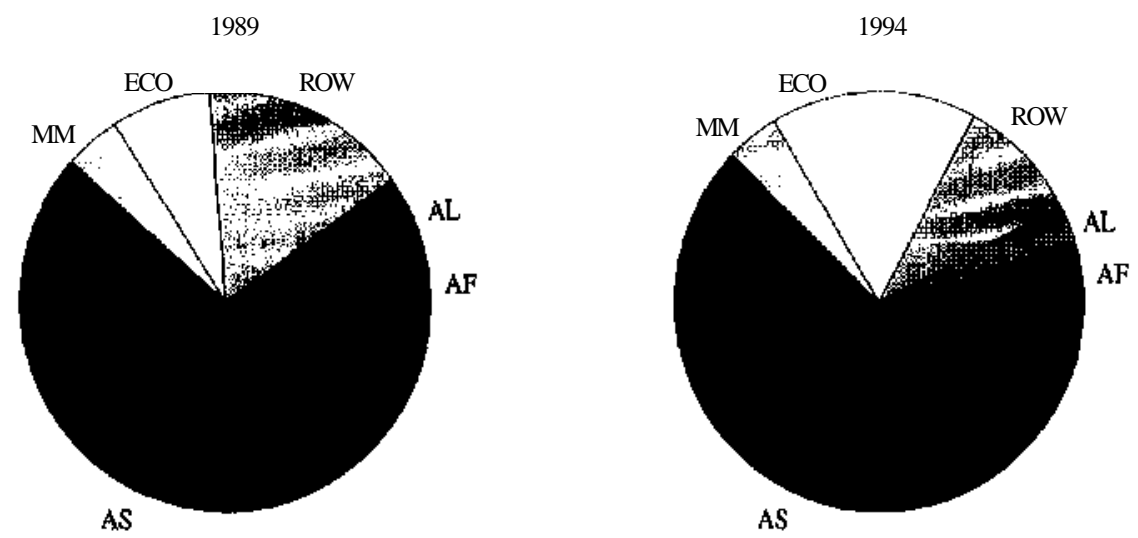

Fuente: Véase el cuadro 2.

$\mathrm{AF} \quad=$ África (excluidos Argelia, Egipto, Libia, Marruecos, Túnez y la República de Sudáfrica)

$\mathrm{AS}=$ Asia (excluido el Oriente Medio)

$\mathrm{ECO}=$ Europa central y oriental (excluida la Comunidad de Estados Independientes)

$\mathrm{AL}=$ América Latina

MM = Países del Magreb $y$ del Mashrek (excluido el Líbano)

$\mathrm{ROW}=$ Resto de países no pertenecientes a la OCDE.

bajó en varias industrias manufactureras (véase el cuadro 2).

Las políticas comerciales de la Unión Europea en general y el trato preferencial otorgado a los países de Europa central y oriental en particular, no pueden explicar los resultados dispares obtenidos por países no favorecidos en la penetración de los mercados de la Unión Europea. América Latina perdió cuotas de mercado en beneficio de otros en el comercio con la Unión Europea, ya fuera que tuvieran un acceso privilegiado a ese mercado (países de Europa central y oriental) o que estuvieran sometidos a un trato discriminatorio (países asiáticos). Se desprende que la peor actuación de América Latina en los mercados de la Unión Europea tiene que deberse en primer lugar a las restricciones de la oferta interna, que, sobre todo para las manufacturas, deben considerarse como secuela de prolongadas políticas de sustitución de importaciones. Estas mermaron la capacidad de competencia internacional de los fabricantes latinoamericanos.

Las reformas de la política comercial para superar este problema habrían tardado demasiado en mostrar su eficacia. Sin embargo, los datos por países indican que los primeros reformadores latinoamericanos se desenvolvieron relativamente bien en los mercados de bienes manufacturados de la Unión Europea. En el período 1989-1994 Chile fue el único que evitó una disminución de su participación en las importaciones de manufacturas de la Unión Europea provenientes de todos los países no miembros de la OCDE (véase el cuadro 2). Al otro extremo está Brasil, donde las reformas económicas se aplazaron hasta hace poco. La participación de este país en las importaciones manufactureras de la Unión Europea provenientes de países no pertenecientes a la OCDE se redujo a la mitad, es decir, a $2.2 \%$ en 1994. Argentina y México se sitúan entre estos extremos. Las tendencias por industria confirman que se deterioró con mayor intensidad la posición de los retrasados en materia de reformas. Por ejemplo, la participación de Brasil en las importaciones de maquinaria y. equipo de transporte de la Unión Europea provenientes de países no miembros de la OCDE bajó de $5.6 \%$ a $2.1 \%$ en 1989-1994, siendo pequeña la pérdida correspondiente para México (véase el cuadro 2). El gráfico 2 subraya el vínculo entre las reformas de la política interna y el comportamiento de las exportaciones. Brasil registró una gran disminución en su participación en las exportaciones de manufacturas de América Latina a la Unión Europea en 1994. El más favorecido fue México, pero exportadores no tradicionales como Chile también ganaron terreno. El papel decisivo de la política económica interna es también evidente cuando se trata de explicar la estructura de la inversión extranjera directa. 


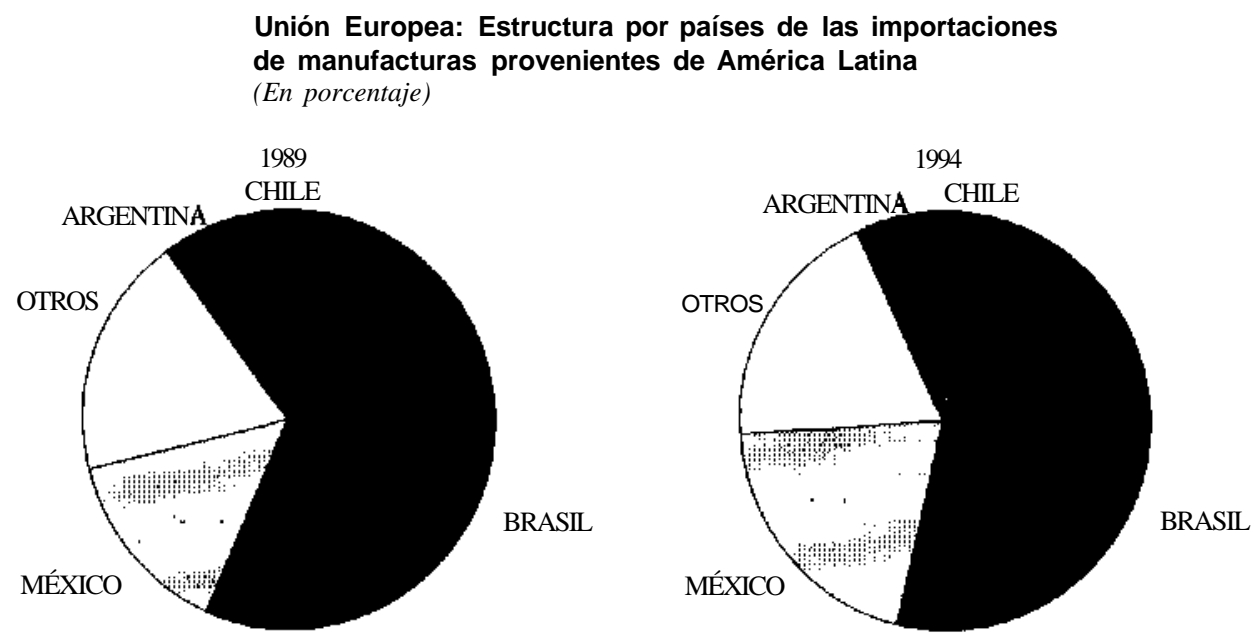

Fuente: Véase el cuadro 2.

\section{La inversión extranjera directa de la Unión Europea: por qué es improbable un juego de suma cero}

1. Los países de Europa central y oriental como nuevos competidores por la Inversión extranjera directa ¿una amenaza para América Latina?

Entre los países no miembros de la OCDE, América Latina ha sido tradicionalmente la principal receptora de la inversión extranjera directa de la Unión Europea. Un $45 \%$ de las inversiones extranjeras directas de los cuatro principales inversionistas de la Unión Europea (Francia, Alemania, Países Bajos y Reino Unido).dirigidas a todos los países no miembros de la OCDE se hallaba en América Latina en 1985 y en 1990 (véase el gráfico 3). Un $60 \%$ de la inversión de seis países de la Unión Europea ${ }^{16}$ al área no perteneciente a la OCDE se destinó a América Latina en el período 1985-1997 (OCDE, 1996).

Los países de Europa central y oriental casi no existían como competidores por la inversión extranje-

\footnotetext{
${ }^{16}$ También se dispone de datos para Dinamarca y España. Los datos de la OCDE para los restantes países de la Unión Europea son incompletos, inconsistentes o inexistentes (OCDE, 1996).
}

ra directa hasta el derrumbe del socialismo. Entre 1985 y 1987 seis países de la Unión Europea invirtieron apenas un promedio anual de 20 millones de dólares en Europa central y oriental, en comparación con 2500 millones de dólares en América Latina (OCDE, 1996). El gráfico 3 muestra que el nivel de la inversión extranjera directa de la Unión Europea en esos países era muy bajo hasta hace poco.

Sin embargo, la inversión extranjera directa afluyó extraordinariamente a los países de Europa central y oriental cuando comenzaron a transformarse en economías de mercado. La proveniente de los seis países de la Unión Europea se multiplicó 13 veces hasta llegar a 2700 millones de ECU en 1994 (véase el gráfico 4). En cambio, la de América Latina bajó mucho en los tres años siguientes a 1990 y sólo registró un repunte significativo en 1994.

Cabe esperar que los países de Europa central y oriental candidatos a ingresar a la Unión Europea se vuelvan receptores todavía más atractivos en el futuro. Los pasos previos encaminados a una integración más estrecha con la Unión Europea han promovido la inversión extranjera directa en los países miembros de 
GRÁFICO 3

Unión Europea: Distribución regional de la Inversión extranjera directa de cuatro países* en países no pertenecientes a la OCDE, ${ }^{\text {b } 1985-1994}$

(En porcentaje)

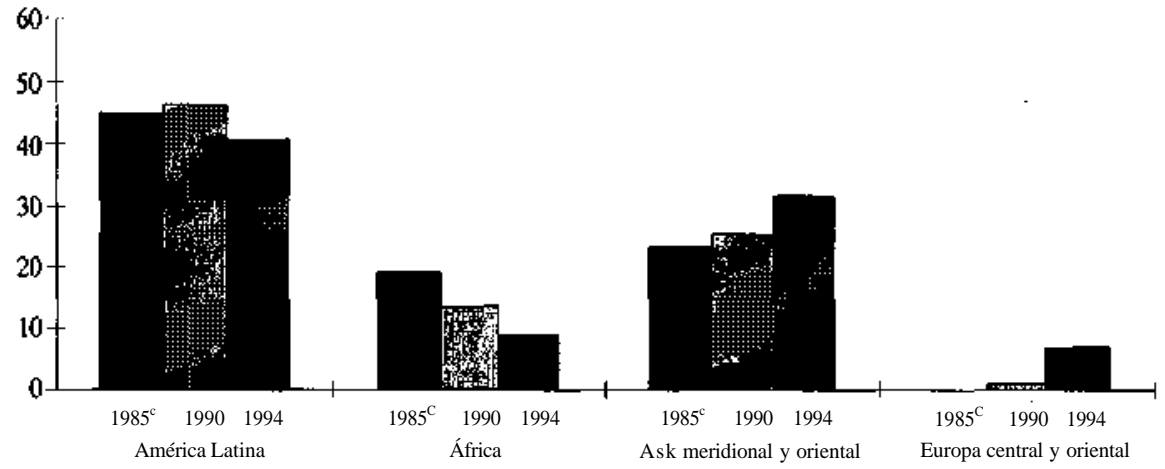

Fuente: OCDE (1966)

a Francia, Alemania, Países Bajos y Reino Unido, b Incluido México, $\quad$ c 1987 para Francia y el Reino Unido.

GRÁFICO 4

Unión Europea: Inversión extranjera directa de seis países ${ }^{8}$ en reglones seleccionadas, 1990-1994

Miles de

millones de ECU

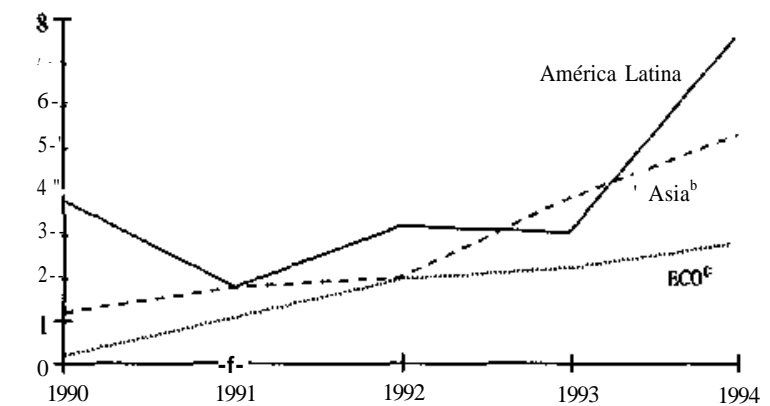

Fuente: OCDE (1996).

a Dinamarca, Francia, Alemania, Países Bajos, España y Reino Unido.

b Excluido el Oriente Medio.

Europa central y oriental, incluida la ex Unión Soviética.

ella en varios casos. España, pọ ejemplo, surgió como gran receptor de inversiones después que el país se incorporó a la Unión Europea en $1986 .{ }^{17}$ Para la Unión Europea en su conjunto, el programa del mercado interno ofreció un estímulo considerable a las corrientes

${ }^{11}$ La afluencia de inversión de todas las fuentes a España se disparó de 2600 millones de ECU en 1985-1986 a 5600 millones de ECU en 1987-1988 y a 11800 millones de ECU en 1989-1990 (promedios anuales). El incremento más acentuado se dio en la afluencia a España de otros miembros de la Unión Europea, la que se sextuplicó con creces a 7300 millones de ECU en 1989-1990 (OCDE, 1996). intrarregionales de inversión extranjera directa (Agarwal, Hiemenz y Nunnenkamp, 1995). ${ }^{18}$

Todo esto sugeriría que América Latina tiene mucho que perder como receptor de inversión extranjera directa. Sin embargo, como en el comercio, la atracción que ejerce la región sobre la inversión tiene poco que ver con la integración de la Unión Europea y el surgimiento de posibles candidatos a miembros de ella como nuevos competidores por esa inversión. Respalda esta tesis el examen más detenido de los patrones recientes de inversión extranjera directa. Asimismo, el examen de las motivaciones de los inversionistas en los distintos tipos de inversión revela que es probable que siga siendo de poco monto la desviación de la misma en el futuro. ${ }^{19}$

\section{La inversión extranjera directa ¿cómo explicar su falta de atractivo?}

Varias observaciones empíricas contradicen la idea de que América Latina se haya visto muy afectada por la desviación de la inversión extranjera directa resultante de la integración de la Unión Europea y del establecimiento de vínculos más estrechos con los países

\footnotetext{
${ }^{18}$ La participación intrarregional en la salida total de inversión extranjera directa de los países de la Unión Europea se duplicó de $31 \%$ en $1985-1987$ a $63 \%$ en $1990-1992$.

${ }^{19}$ En contraste con la desviación del comercio, la noción de desviación de la inversión extranjera directa carece de fundamento analítico. Utilizamos este término llamativo para englobar los posibles efectos de una competencia más dura por la inversión entre sus receptores tradicionales.
} 
de Europa central y oriental. En primer lugar, si la desviación hubiera sido un factor influyente, todos los receptores no pertenecientes a la OCDE habrían sufrido por el mayor atractivo de los países de Europa central y oriental. En particular, a las regiones en desarrollo de Asia no les habría ido mejor que a América Latina. En cambio, el vuelco más espectacular en la distribución regional de la inversión extranjera directa entre todos los países no pertenecientes a la OCDE ocurrió precisamente entre estas dos regiones (Gundlach y Nunnenkamp, 1966, gráfico 1): la participación de Asia oriental en las inversiones extranjeras directas totales casi se cuadruplicó desde 1980, mientras que la de América Latina se deterioró ostensiblemente. Lo propio es válido para la inversión extranjera directa de la Unión Europea. Aunque los inversionistas de la Unión han estado tradicionalmente subrepresentados en Asia, de los gráficos 3 y 4 de desprende una evidente diversión de esas corrientes de América Latina al Asia, ${ }^{20}$

Por otra parte, América Latina perdió su atractivo para la inversión extranjera directa sobre todo en el decenio de 1980, antes que los países de Europa central y oriental tuvieran influencia alguna. La participación de la región en las corrientes mundiales de inversión extranjera directa bajó de $12.6 \%$ en el período 1979-1982 a menos de 4\% en 1990 (FMI, Balance of Payments Statistics Yearbook, varios números). Y lo que es más notable, la participación de América Latina se recuperó precisamente cuando los países de Europa central y oriental salieron a relucir como nuevos competidores por esa inversión. La participación de América Latina se mantuvo siempre más decaída en 1991-1995 que en 1979-1982, pero, en promedio, sé duplicó en relación con 1990.

Además, el aumento reciente de la afluencia total de inversión extranjera directa a América Latina se debe sobre todo al crecimiento de la inversión proveniente de los Estados Unidos (BID/IRELA, 1996; cuadro 11), Ahora último, sin embargo, también los inversionistas de la Unión Europea ampliaron sus compromisos en la región (véase el gráfico 4). Es difícil que el incremento relativamente pequeño de la inversión pro-

\footnotetext{
${ }^{20}$ Las corrientes de inversión extranjera directa de seis países de la UE a Asia representaban menos de un tercio de esa inversión a América Latina en 1990. Esta relación sube a casi $90 \%$ cuando se comparan los promedios anuales en 1993-1994 (véase el gráfico 4). Para un análisis más detallado, véase Comisión Europea/UNCTAD (1996). ${ }^{21}$ Según los datos suministrados por BID/IRELA (1996, cuadro 11), la afluencia de inversión europea a América Latina durante el período 1990-1994 fue 65\% mayor que en el segundo lustro de la década de 1980. En comparación, la inversión extranjera directa de los Estados Unidos se sextuplicó.
}

veniente de Europa ${ }^{21}$ se deba a un fenómeno de desviación, a menos que se sostenga que este incremento habría sido más acentuado si los países de Europa central y oriental no hubieran absorbido la creciente inversión de la Unión Europea (lo que no puede comprobarse). Más bien, se trata de que la inversión estadounidense en América Latina es en general más volátil que la de la Unión Europea: el auge de la inversión proveniente de los Estados Unidos partió de un nivel deprimido en 1985-1989, en tanto que las corrientes de inversión extranjera directa de Europa a América Latina fueron incluso algo mayores en 1985-1989 que en 1980-1984.

Por último, cabe señalar que los distintos países receptores de América Latina lograron resultados muy diferentes en su empeño por atraer inversión extranjera directa. ${ }^{22}$

- Brasil, que solía estar muy a la cabeza como receptor de inversión extranjera directa en la región registró una caída abrupta en su participación en la afluencia de inversiones extranjeras directas de toda fuente a América Latina.

- México y, ahora último, también Argentina, superaron a Brasil en la afluencia total de inversión extranjera directa.

- Chile y Argentina registraron los más altos promedios de la afluencia anual de inversión extranjera directa per cápita en 1991-1995.

Aunque Brasil siguió siendo el receptor más importante de inversión extranjera directa proveniente de la Unión Europea (véase el cuadro 3), esas corrientes se desviaron notoriamente hacia otros países latinoamericanos. A semejanza de lo ocurrido con los movimientos mundiales de inversión extranjera directa, Argentina y México (en los años noventa) y Chile (desde comienzos de los ochenta), fueron los principales beneficiarios de la mayor afluencia de inversiones provenientes de la Unión Europea. ${ }^{23}$ Estos cambios parecen estar estrechamente correlacionados con las políticas económicas aplicadas por los gobiernos (Nunnenkamp, 1997a). Recuérdese que Chile es el precursor de las reformas económicas en América Latina, pero el vínculo entre la oportunidad de las reformas y el mayor atractivo para la inversión extran-

\footnotetext{
${ }^{22}$ Para un análisis detallado y fuentes de datos, véase Nunnenkamp (1997a).

${ }^{23}$ La participación creciente del resto de América Latina sugiere que los inversionistas de la Unión Europea aumentaron también sus compromisos en varias economías más pequeñas de la región. Entre otros ejemplos figuran Jamaica, Perú y Trinidad y Tabago (BID/ IRELA, 1996, anexo estadístico, cuadro 23).
} 
CUADRO 3

Participación de cuatro economías latinoamericanas importantes en la inversión extranjera directa de la Unión Europea hacia la región, ${ }^{a}$ 1980-1994 (En porcentaje)

\begin{tabular}{lccc}
\hline & $1980-1984$ & $1985-1989$ & $1990-1994$ \\
\hline Argentina & 16.7 & 14.4 & 18.2 \\
Brasil & 50.3 & 51.1 & 29.0 \\
Chile & 5.8 & 9.2 & 8.9 \\
México & 12.1 & 8.9 & 14.9 \\
Otros & 15.1 & 16.4 & 29.0 \\
\hline
\end{tabular}

Fuente: BID/IRELA (1996, cuadro 23).

${ }^{a}$ Promedio anual. Se excluye la inversión extranjera directa a los centros financieros extraterritoriales.

jera directa también se da en los casos de Argentina y México.

Como conclusión, cabría señalar que los pésimos resultados obtenidos por el Brasil en sus esfuerzos por atraer inversión extranjera directa son consecuencia de su gran dilación en aplicar las reformas del caso. ${ }^{24}$

En suma, la desviación de la inversión extranjera directa resultante de la integración europea parece haber sido un factor secundario en la configuración de los patrones recientes de esa inversión. Tanto la inversión directa mundial como la europea distan de ser un juego de suma cero. Varias economías latinoamericanas han recuperado su atractivo para la inversión, precisamente cuando los países de Europa central y oriental surgen como nuevos competidores por ese recurso. Los países de ambas regiones se beneficiaron simultáneamente de un incremento de la inversión, luego de haber aplicado programas de estabilización y ajuste estructural. La redistribución reciente de la inversión extranjera directa entre las regiones y entre las economías latinoamericanas guarda estrecha correlación con la aplicación oportuna y sistemática de reformas económicas.

\section{Motivaciones de los inversionistas de la Unión Europea ¿prejuiciados contra América Latina?}

Corresponde averiguar si la integración más estrecha de la Unión Europea en el futuro se traducirá o no en una desviación de la inversión extranjera directa en perjuicio de América Latina. La evaluación de diferen-

\footnotetext{
${ }^{24}$ Para un análisis detallado del caso de Brasil, véase Nunnenkamp (1997b).
}

tes sectores y de las motivaciones de los inversionistas extranjeros podrían dar algunas pistas, ${ }^{25}$ ya que es razonable suponer que el potencial de desviación de la inversión extranjera directa difiere notoriamente entre los diversos tipos de inversión (Agarwal, 1994).

En esencia, la inversión extranjera directa tiene tres motivaciones: i) aprovechar las materias primas y los recursos naturales disponibles en el país receptor, ii) abastecer los mercados internos de los países o regiones receptores, y iii) emplear las plazas externas como plataformas para la producción basadas en el ensamblaje de piezas producidas en distintos lugares (tercerización) y la comercialización a nivel mundial. El análisis mostrará que la desviación de la inversión extranjera directa casi no tiene sentido en los dos primeros casos. En cambio, la desviación de la inversión extranjera directa sí puede ser una amenaza para el tercer objetivo, pero su materialización depende en gran medida de la propia América Latina.

En cuanto a la inversión extranjera directa para explotar recursos, es muy difícil que América Latina se vea afectada por una desviación a favor de los países de Europa central y oriental que aspiran a acceder a la Unión Europea. Con pocas excepciones, esos países no ofrecen posibilidades de inversión promisorias en el sector minero, sino que dependen marcadamente de las importaciones de minerales y otras materias primas. Desde el punto de vista de la dotación de recursos, la situación es diferente en la agricultura, donde podría haber posibilidades de inversión. No obstante, los datos disponibles sugieren que el sector primario en su conjunto siguió siendo objetivo poco importante de la inversión extranjera directa en los países que postulaban a ser miembros de la Unión Europea a comienzos de los años noventa (Agarwal, 1994, cuadro 4). Es poco probable que. cambie radicalmente el carácter restrictivo de la política agrícola común.

En contraste con los países de Europa central y oriental que quieren ingresar a la Unión Europea, varios estados sucesores de la ex Unión Soviética sí ofrecen enormes oportunidades de inversión en el sector primario, por su buena dotación de recursos naturales. Ello podría provocar una mayor desviación de la inversión extranjera directa si la Unión Europea fortaleciera sus lazos con estos países. Con todo, es difícil que América Latina se vea demasiado afectada. Por ahora siguen sombrías las condiciones de la inversión

\footnotetext{
${ }^{25}$ Para un análisis exhaustivo de las motivaciones de los inversionistas y los posibles efectos de la desviación de la inversión extranjera directa, véase Michalet (1997).
} 
extranjera directa en los estados sucesores de la ex Unión Soviética por la incertidumbre económica y política que los afecta. Por otro lado, varios países receptores latinoamericanos tienen poco que perder. Para Brasil y México, por ejemplo, el sector primario en su conjunto representaba un $2 \%$ del total de la inversión extranjera directa en 1994 (BID/IRELA, 1996, cuadro 8). Por último, la desviación de la inversión extranjera directa sería una preocupación secundaria, incluso en los países latinoamericanos en que el sector primario absorbe gran parte del total, de esa inversión, ${ }^{26}$ ya que la inversión destinada a explotar recursos tiende a estar muy ligada a su emplazamiento, lo que significa que la desviación sólo podría ocurrir cuando varios países ofrecieran la misma calidad de un mismo producto.

La inversión extranjera directa destinada a servir los mercados internos de los países receptores (en la jerga de la UNCTAD, "la inversión extranjera directa en busca de mercados") parece representar el grueso de esa inversión en América Latina (Nunnenkamp, 1997a). Éste es un supuesto razonable aunque los datos disponibles no permiten establecer una distinción clara entre la inversión en busca de mercado y la aplicada a la terciarización y la comercialización mundiales (la inversión en busca de eficiencia):

- El sector de servicios, en que predominan claramente los no exportables, absorbe una proporción importante de la inversión extranjera directa total en los principales países receptores latinoamericanos. $^{27}$

- Las encuestas a empresas y los análisis de regresión muestran que el tamaño y el crecimiento de los mercados de los países receptores han sido el principal estímulo para que afluyera la inversión al sector manufacturero, sobre todo para América Latina, donde la prolongada aplicación de estrategias de sustitución de importaciones restó incentivos a la afluencia de inversión en busca de eficiencia. La escasa participación de los bienes manufacturados en las exportaciones latinoamericanas a la Unión Europea (véase la sección II.2)

\footnotetext{
${ }^{26}$ Por ejemplo: Bolivia (76\%), Chile (59\%), Colombia (61\%) y Ecuador $(51 \%)$. De los datos disponibles no es posible determinar en qué medida los inversionistas de la Unión Europea están comprometidos en el sector primario de estos países.

${ }^{27}$ La participación del sector servicios en el total de la inversión extranjera directa en 1994 era de un $40 \%$ en Argentina, Brasil y México, y alrededor de un 25\% en Chile (BID/IRELA, 1996, cuadro 8). Además, la afluencia reciente de inversión extranjera directa a varios países latinoamericanos se concentró en los servicios, en gran parte por efecto de los programas de privatización (Nunnenkamp, 1997a).
}

confirma que la inversión de la Unión Europea en el sector manufacturero ha privilegiado la búsqueda de mercados en la región.

La distribución sectorial de la inversión extranjera directa en varios países de Europa central y oriental sugiere que, a semejanza de América Latina, la inversión en busca de mercados predominaba a principios de los años noventa (Agarwal, 1994, p. 12) y así lo corroboraron los resultados de varias encuestas recientes (OCDE, 1993 y Michalet, 1997). Esta similitud entre América Latina y los países de Europa central y oriental probablemente reduce las posibilidades de desviación de la inversión extranjera directa. Es casi inconcebible que los inversionistas de la Unión Europea hayan renunciado a mercados importantes en América Latina simplemente por haberse presentado nuevas posibilidades en los países de Europa central y oriental. Más bien, cabe esperar un aumento de la inversión si diferentes regiones ofrecen perspectivas favorables de mercado, ${ }^{28}$ lo que confirma el auge reciente de la inversión extranjera directa en el sector de servicios de varios países de América Latina, Europa central y oriental y otras regiones, cuando adhirieron a la tendencia mundial hacia la privatización y la desreglamentación.

En conclusión, la inversión extranjera directa en busca de mercados depende de las perspectivas económicas de los países latinoamericanos y no del curso futuro de la integración de la Unión Europea y de que se mantenga la recuperación reciente de la afluencia de inversión extranjera directa a la región, sin por ello desconocer que el predominio de la inversión extranjera directa en busca de mercados implica ciertos riesgos para América Latina. En forma indirecta, podría dejar en desventaja a las economías latinoamericanas para competir por el tercer tipo de inversión, es decir, la que busca la eficiencia.

En la era de la globalización, la inversión extranjera directa en busca de la eficiencia sería la respuesta distintiva de las empresas multinacionales a un medio internacional cambiante (UNCTAD, 1996, p. 97). Se espera que disminuya la importancia relativa del tamaño de los mercados de los países receptores, como uno de los determinantes tradicionales más importantes de la llegada de la inversión. En esas condiciones, América Latina estaría en desventaja frente a otras regiones.

\footnotetext{
${ }^{28}$ El incremento de la inversión extranjera directa podría ir acompañado de una inversión interna relativamente más baja en los países de la Unión Europea. A diferencia de la desviación este fenómeno podría calificarse de "creación de inversión extranjera directa" (en analogía con la creación del comercio).
} 
La globalización puede inclinar aún más la balanza en favor de Asia. Varios países asiáticos son bien conocidos por su orientación hacia el mercado mundial, lo que los sitúa en una posición favorable para competir por la inversión extranjera directa en busca de la eficiencia. En cambio, es posible que los países latinoamericanos sigan afectados por una insuficiente competitividad internacional de sus industrias manufactureras, establecidas bajo el signo de la sustitución de importaciones. Al propio tiempo, la tendencia a la liberalización del comercio en América Latina le resta incentivos a los inversionistas extranjeros para realizar inversiones en busca de mercados en esta región, pretendiendo sortear las barreras proteccionistas.

Asimismo, podría ser más difícil para América Latina que para los países de Europa central y oriental atraer la inversión en busca de la eficiencia. El repunte reciente de la inversión en busca de mercados en los países de Europa central y oriental ocurrió cuando ellos liberalizaban considerablemente sus regímenes de comercio exterior. Por lo tanto, la inversión efectuada en esos países quizá esté más alineada con sus ventajas comparativas que la de los países latinoamericanos, con lo cual les sería relativamente fácil pasar de una inversión en busca de mercados a otra en busca de la eficiencia. Los países de Europa central y oriental poseen otras dos ventajas para atraer la inversión en busca de eficiencia: la proximidad geográfica, ya que la distancia encarece los costos de transacción y, el acceso preferencial a los mercados de la Unión Europea.

El máximo potencial de desviación se da en el campo de la inversión en busca de eficiencia. En el contexto de la globalización, las perspectivas generales en materia de inversión extranjera directa parecen depender cada vez más de lo atractivo que sea un lugar para la inversión en busca de la eficiencia. De ser así, a las economías latinoamericanas no les queda otro remedio que prepararse para una competencia mundial más dura por este tipo de inversión. Varios países latinoamericanos han tomado ya medidas importantes para reducir el riesgo de desviación de la inversión extranjera directa. Los programas de reforma integral relativos a la estabilización macroeconómica y el ajuste estructural fueron decisivos para la recuperación reciente de la afluencia de inversión a América Latina (Nunnenkamp, 1997a). El estrecho vínculo entre la mentalidad reformadora y la afluencia de inversión extranjera directa respalda la tesis de que las perspectivas futuras de América Latina para atraer la inversión en busca de eficiencia descansan sobre todo en las políticas económicas que se sigan en la región, y no tanto en un proceso de integración más estrecho y de ampliación de la Unión Europea.

\section{IV}

\section{Perspectiva futuras}

\section{1. ¿Hacía una mayor desviación del comercio?}

Las modalidades recientes del comercio y de la inversión extranjera directa indican que la extensión de la Unión Europea hacia el este tiene escasos efectos sobre América Latina. En cuanto al comercio, los países de Europa central y oriental y los latinoamericanos parecen haber enfocado distintos mercados para sus exportaciones a la Unión Europea. El hecho de que sean escasas las superposiciones del comercio implica que también es exigua la desviación del comercio resultante de la integración de la Unión Europea perjudicial para América Latina. Esta situación podría variar un poco cuando varios países de Europa central y oriental accedan a la Unión. Sin embargo, no debería variar radicalmente el cuadro futuro, máxime si los posibles cambios obran en direcciones encontradas de modo que sus efectos sobre la desviación del comercio se anulen entre sí.

$\sim$ El potencial de desviación del comercio seguirá disminuyendo una vez que se apliquen plenamente los acuerdos de la Ronda Uruguay. Entonces disminuirán los márgenes de preferencia para los países de Europa central y oriental, que representan una desviación del comercio en áreas "sensibles" como los textiles y el vestuario. Por otra parte, las superposiciones del comercio podrían reducirse aún más en el futuro, si los países de Europa central y oriental logran aprovechar mejor su dotación relativamente favorable de capital humano y de mano de obra calificada. Con una inversión continua que permita reemplazar los equipos de capital obsoletos heredados del pasado socialista, la 
ventaja comparativa de estos países se situará en las líneas de producción muy especializadas. El aumento de los salarios durante el proceso de trans formación económica e integración a la Unión Europea fortalecerá el cambio estructural hacia industrias manufactureras más sofisticadas. En tal caso, la oferta de los países de Europa central y oriental en los mercados de la Unión Europea sería cada vez más complementaria, en vez de sustitutiva, de la oferta latinoamericana.

- El ingreso a la Unión Europea de algunos de estos países podría provocar más desviación del comercio ya que se eliminarán las barreras comerciales remanentes entre estos países y los miembros actuales de la Unión Europea. Por su parte, los países de Europa central y oriental tendrán que reducir su nivel de protección (relativamente elevado) frente a los no miembros de la Unión Europea al nivel de protección externa (relativamente reducido) de la Unión actual. Los requisitos de un área de libre comercio y una unión aduanera, considerados en conjunto, pueden dar origen a profundas necesidades de ajuste estructural en los nuevos países miembros de la Unión Europea. Contra este telón de fondo, esos países tendrán que dirigirse probablemente a la Unión Europea para que considere su mayor demanda de protección cuando se entablen negociaciones comerciales con los no miembros. Es así como una Unión ampliada tendería a hacer más lento el proceso de liberalización del comercio externo, sobre todo durante el período de ajuste estructural en los países de Europa central y oriental, para atenuar las presiones de los miembros actuales de la Unión Europea y de los países no miembros (Langhammer y Nunnenkamp, 1993).

Es casi imposible lograr un equilibrio razonable entre estas influencias antagónicas, y menos aún evaluar el impacto neto sobre determinados países que comercian con la Unión Europea, como los latinoamericanos. Aunque la desviación del comercio se vuelva más probable, surgirán al mismo tiempo nuevas posibilidades de comercio. América Latina puede verse afectada si la Unión Europea se vuelve más renuente a liberalizar su comercio exterior. Los proveedores latinoamericanos se beneficiarán de un mejor acceso a los mercados aún altamente protegidos de los países de Europa central y oriental, una vez que formen parte de la unión aduanera, lo que contribuiría a elevar la bajísima participación de Europa central y oriental en las exportaciones latinoamericanas totales (1994: 0.3\%, excluida la ex Unión Soviética; Naciones Unidas, 1996).

\section{2. ¿Hacia una mayor complementación entre el comercio y la inversión extranjera directa?}

A semejanza del comercio, América Latina enfrenta cierto peligro de desviación de la inversión extranjera directa. Sin embargo, por varias razones no hay que sobreestimarlo. Las corrientes mundiales de inversión extranjera directa no han sido nunca - y es muy improbable que alguna vez lo sean- un juego de suma cero. El repunte reciente de la inversión extranjera directa a varios países y regiones receptores, incluso muchas economías latinoamericanas, indica que las nuevas posibilidades de inversión hacen subir la inversión extranjera directa, en vez de desviarla. Los temores de desviación tienden a ser exagerados, si se toma en cuenta que la inversión extranjera directa no es un fenómeno uniforme: son distintas las motivaciones de la inversión en busca de recursos o de mercados o de eficiencia. El peligro de desviación de la inversión extranjera directa se limita esencialmente a la que busca eficiencia, pero cabe esperar que ese tipo de inversión cobre cada vez mayor importancia en la era de la globalización.

La tendencia actual hacia la producción y comercialización globalizadas puede tener importantes repercusiones sobre la relación entre el comercio y la inversión extranjera directa (véase asimismo UNCTAD, 1996, capítulo IV). En cierta medida, y en determinadas condiciones, la inversión puede todavía ser un sustituto del comercio. Por ejemplo, puede seguir al comercio una vez que se ha conquistado cierta cuota de mercado mediante las exportaciones, o puede emplearse para superar las barreras a la importación. Brasil, por ejemplo, parece haber sido el mayor receptor de inversión en busca de mercados entre los países en desarrollo antes de la crisis de su deuda externa, debido sobre todo a que las políticas de sustitución de importaciones habían obstaculizado el comercio. Sin embargo, en su sentido más tradicional, la posibilidad de sustitución del comercio por la inversión extranjera directa se ve amenazada por la tendencia a la globalización. Las empresas multinacionales al parecer, consideran cada vez con mayor frecuencia que el comercio y la inversión extranjera directa son formas complementarias de atender los mercados y organizar la producción. Una industria manufacturera geográficamente dispersa así como la conjunción de mercados y recursos mediante la inversión extranjera directa $y$ el comercio se están convirtiendo en parte importante de la economía mundial: 
- Con la inversión extranjera directa, las empresas multinacionales segmentan la cadena de producción y capitalizan las diferencias de costos internacionales. Instalan sus procesos productivos donde se encuentra la mayor ventaja comparativa.

- Las empresas multinacionales aportan unos dos tercios de las exportaciones mundiales de bienes y de servicios no atribuibles a factores (UNCTAD, 1995, p. 193). Alrededor de la mitad de las exportaciones de las empresas multinacionales son intraempresariales, proporción que parece ir en aumento.

Los anáfisis empíricos muestran una correlación positiva entre las corrientes comerciales y las de inversión extranjera directa, lo que indica que los efectos de complementación entre el comercio y la inversión extranjera directa predominan sobre los de sustitución (Nunnenkamp, Gundlach y Agarwal, 1994, pp. 81 y siguientes). La inversión se correlaciona positivamente no sólo con las exportaciones de los países de origen de los inversionistas hacia los países receptores, sino también con las exportaciones de los países receptores hacia los países de origen. Por lo tanto, en vez de reemplazar al comercio con los países en desarrollo, es probable que el auge reciente de la inversión extranjera directa intensifique las relaciones comerciales,

\section{3. ¿Cómo lograr relaciones económicas más es- trechas?}

La complementación entre el comercio y la inversión extranjera directa no sólo ayuda a los países en desarrollo a acceder a los recursos para fortalecer su capacidad productiva, sino también a penetrar los mercados mundiales con productos en cuya elaboración tienen ventajas comparativas, Sin embargo, estos países deben cumplir varios requisitos para participar en la producción globalizada y mejorar así las perspectivas de atraer la inversión extranjera directa y penetrar los mercados mundiales. La comparación entre países sugiere que los siguientes factores merecen prioridad: la estabilidad macroeconómica sostenida, la apertura a los mercados mundiales, y la acumulación de capita! físico y humano (Sachs y Warner, 1995; Gundlach y Nunnenkamp, 1996 y Nunnenkamp, 1996).
De ahí que el curso que sigan las relaciones económicas con la Unión Europea dependerá en lo fundamental de las políticas económicas que apliquen los gobiernos latinoamericanos. Varios de estos países están empeñados en restablecer su competitividad internacional y en atraer a la inversión extranjera directa, pero subsisten grandes obstáculos. Aunque el grueso de la inversión extranjera directa tradicionalmente ha buscado los mercados de América Latina, la región ya no puede seguir contando con el tamaño del mercado local o regional como incentivo para la inversión extranjera directa. Para aprovechar los beneficios de la complementación entre el comercio y la inversión, América Latina debe aumentar los alicientes para el ingreso de la inversión extranjera directa en busca de la eficiencia. Una cuestión decisiva es la capacidad de competencia de las industrias manufactureras de sustitución de importaciones que los inversionistas extranjeros ayudaron a establecer de acuerdo con los cánones internacionales. El equipo de transporte y la electrónica ofrecen un buen ejemplo ya que el comercio intraempresarial cumple un papel destacado en estas industrias (UNCTAD, 1995, p. 197). A corto plazo, América Latina está ante una disyuntiva: la liberalización comercial puede tener efectos negativos sobre las formas tradicionales de inversión extranjera directa, ya que resta incentivos para destinarla a superar las barreras a la importación. A largo plazo, en cambio, esa liberalización y la desreglamentación de la inversión extranjera directa son decisivas para la incorporación de América Latina en la producción globalizada, ya que fomenta la especialización conforme a las ventajas comparativas.

La reforma sostenida de las políticas económicas puede considerarse como el aporte de América Latina para que prosperen las relaciones económicas con la Unión Europea. La contribución más importante de ésta sería asegurar mercados abiertos para los países no miembros, incluso los latinoamericanos, y representar un papel constructivo en el mantenimiento de un sistema comercial multilateral liberal. La extensión de la Unión Europea hacia el este supone naturalmente cierto riesgo para la liberalización de su comercio externo, y podría aumentar más el peligro de que la Unión Europea extreme sus políticas aislacionistas si la integración en ella no sigue una evolución expedita.

(Traducido del inglés) 


\section{Bibliografía}

Agarwal, j. P. (1994): Impact of "Europe Agreements"tin FDl in developing countries. Working papers, $\mathrm{N}^{\circ}$ 640, Kiel, Alemania, Instituto de Economía Mundial.

Agarwal, J. P., U, Hiemenz y P. Nunnenkamp (1995): European integration: A threat to foreign investment in devoloping countries?, Discussion papers, $\mathrm{N}^{\circ} 246$, Kiel, Alemania, Instituto de Economía Mundial.

Agarwal, J.P., R.J. Langhammer, M Lücke y P, Nunnenkamp (1995): Export expansion and diversification in Central and Eastern Europe: What can be learnt from East and Southeast Asia?, Discussion papers, $\mathrm{N}^{\circ} 621$, Kiel Alemania, Instituto de Economía Mundial.

BID (Banco Interamericano de Desarrollo)/IRELA (Instituto de Relaciones Europeo-Latinoamericanas) (1996): Inversión extranjera directa en América Latina en los años 90, Madrid.

Comisión Europea/UNCTAD (Conferencia de las Naciones Unidas sobre Comercio y Desarrollo (1996): Investing in Asia's Dynamism, Luxemburgo, European Union Direct Investment in Asia.

FMI (Fondo Monetario Internacional): Balance of Payments Statistics Yearbook (varios números), Washington, D.C.

Gundlach, E., y P. Nunnenkamp (1996): Some consequences of globalization for developing countries, Working papers, $\mathrm{N}^{\circ}$ 753, Kiel, Alemania, Instituto de Economía Mundial.

Hiemenz, U., E. Gundlach, R.J. Langhammer y P. Nunnenkamp (1994): Regional integration in Europe and its effects on developing countries, Kiel Studies, $\mathrm{N}^{\circ}$ 260, Tubingen, Alemania.

Koester, U. (1996): EU agricultural policy towards CEECs: The impact on LDCs, A. Kuyvenhoven, O. Memedovic y N. Van der Windt (eds.), Transition in Central and Eastern Europe; implications for EU-LDC relations, Dordrecht.

Langhammer, R,J, (1994): Latin America's competitive position visà-vis Central and Eastern Europe. Comment on András Inotai, B. Fischer, A. von Gteich y W. Grabendorff (eds.). Latin America's competitive position in the enlarged European Market, Baden-Baden, Alemania.

Langhammer, R.J. y P. Nunnenkamp (1993): Implications of the Europe agreements for Latin America, Kiel, Alemania, Instituto de Economía Mundial.

Michalet, C.A. (1997): Investment strategies of multinational corporations and the attractiveness of host countries. The impact of the opening of Central and Eastern Europe on the location of foreign direct investment, Washington, D.C, Banco Mundial, Servicio de Asesoría sobre Inversión Extranjera. Naciones Unidas (1996): Monthly Bulletin of Statistics, vol. 50, $\mathrm{N}^{\circ}$ 5, Nueva York, mayo.

Nunnenkamp, P. (1996): Winners and losers in the global economy: recent trends in the international division of labour and policy challenges, Discussion papers, $\mathrm{N}^{\mathrm{O}} 281$, Kiel, Alemania, Instituto de Economía Mundial.

(1997a): Foreign direct investment in Latin America in the era of globalized production, Transnational Corporations, vol, 6 , $\mathrm{N}^{\circ} 1$, Nueva York, Naciones Unidas.

(1997b): Herausforderungen der Globalisierung fur Brasilien, Die Wettwirtschaft, $\mathrm{N}^{\circ} 1$.

Nunnenkamp, P., E. Gundlach y J.P. Agarwal (1994): Globalisation of production and markets, Kiel Studies, $\mathrm{N}^{\circ} 262$, Tubingen, Alemania.

OCDE (Organización de Cooperación y Desarrollo Económicos) (1993): Summary Record of the Meeting of Advisory Group on Investment, Varsovia, 7 al 8 de julio.

(1996): International Direct Investment Statistics Yearbook, Pan's

(Varios números): Foreign Trade by Commodities. Series $C$, Paris.

OMC (Organización Mundial del Comercio)(1995): Trade policy review: European Union. Report by the Secretariat, Documento WT/TPR/S/3, Ginebra.

Piazolo, D. (1997): Trade integration between Eastern and Western Europe: Policies follow the market, Journal of Economic Integration, vol. $12, \mathrm{~N}^{\circ} 3$.

Sachs, J.D., y A. Warner (1995): Economic convergence and economic policies, Working papers, $\mathrm{N}^{\circ}$ 5039, Cambridge, Massachusetts, National Bureau of Economic Research.

UE (Unión Europea), EUROSTAT (Oficina de Estadística) (1995): External Trade: System of Generalized Tariff Preferences, Luxemburgo.

UNCTAD (1995): Informe sobre las inversiones en el mundo, 1995. Las empresas transnacionales y la competitividad, Ginebra. Publicación de las Naciones Unidas, $\mathrm{N}^{\circ}$ de venta S.95. II.A.9. (1996): Informe sobre las inversiones en el mundo, 1996. Acuerdos en materia de inversión, comercio y política internacional, Nueva York. Publicación de las Naciones Unidas, $\mathrm{N}^{\circ}$ de venta S.96.II.A. 14. 